7 - ORIGINAL ARTICLE

ISCHEMIA-REPERFUSION

\title{
Evaluation of the effect of allopurinol as a protective factor in post ischemia and reperfusion inflammation in Wistar rats ${ }^{1}$
}

\author{
Ricardo Zanetti Gomes ${ }^{\mathrm{I}}$, Gabriela Moreira Mahle Romanek ${ }^{\mathrm{II}}$, Michella Przybycien ${ }^{\mathrm{III}}$, Danielli Cristina Amaral ${ }^{\mathrm{IV}}$, Hugo Genki \\ Kagawa Akahane ${ }^{\mathrm{IV}}$
}

DOI: http://dx.doi.org/10.1590/S0102-865020160020000007

IPhD, Head, Medicine Department, Universidade Estadual de Ponta Grossa (UEPG), PR, Brazil. Scientific, intellectual, conception and design of the study; interpretation of data; critical revision.

IIGraduate student, School of Medicine, UEPG, Ponta Grossa-PR, Brazil. Scientific and intellectual content of the study, manuscript writing, acquisition of data, technical procedures.

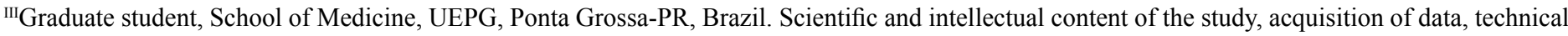
procedures.

${ }^{\mathrm{IV}}$ Graduate student, School of Medicine, UEPG, Ponta Grossa-PR, Brazil. Technical procedures, acquisition of data.

\section{ABSTRACT}

PURPOSE: To investigate the potential protective effect of allopurinol on reperfusion injury by determining the inflammatory response through the measurement of tumor necrosis factor-alpha (TNF-alpha).

METHODS: Sixty rats were distributed into two groups: control and allopurinol and each group was divided into three subgroups, ischemia for two hours, ischemia for three hours and ischemia simulation. Allopurinol group rats received 100mg/kg dose of allopurinol, whereas control group rats received an equivalent dose of saline. Clamping of the infrarenal aorta was performed for two or three hours depending on the subgroup. Ischemia simulation subgroups did not suffer ischemia, just aortic dissection, and maintenance for three hours. After 72 hours of reperfusion, blood was collected by cardiac puncture for TNF-alpha measurement.

RESULTS: Allopurinol reduced TNF-alpha significantly $(\mathrm{p}<0.001)$ when compared to the matching control subgroups $($ control $\mathrm{X}$ allopurinol in ischemia for two hours and for three hours).

CONCLUSION: Allopurinol reduced the concentrations of serum TNF-alpha when used at different times of ischemia followed by reperfusion, which might indicate reduction of the inflammation provoked by the reperfusion injury.

Key words: Ischemia. Reperfusion Injury. Reactive Oxygen Species. Tumor Necrosis Factor-alpha. Allopurinol. Rats. 


\section{Introduction}

Ischemia is defined as the reduction of blood flow and, despite having fundamental role in many perioperative clinic situations, it can also result in several harmful effects to the affected tissues. The adenosine triphosphate (ATP) synthesis depends on oxyreduction reactions which occur at the mitochondrial level. In the lack of oxygen, the cell ATP synthesis is reduced and the energy available is not able to keep the proper functioning of the cell membrane pumps. When these pumps fail, the intra and extra cellular ion normal gradient, which is essential to the cell survival is lost $^{1}$.

Therefore, it is vital that the blood supply is reestablished, in order to prevent irreversible cell damage. Paradoxically, reperfusion per se is able to worsen the ischemic cell damage, which is called reperfusion injury. This occurs because the arrival of oxygen, with consequent formation of oxygen reactive species (ORS), associated to intense participation of neutrophils, increases the inflammatory reaction and results in interstitial and cellular edema, endothelial leukocyte adhesion, microcirculation thrombosis and tissue necrosis ${ }^{2,3}$. Even more relevant is the fact that the ischemia and reperfusion injury (I/R) might lead to systemic complications such as the adult respiratory distress syndrome, kidney and liver malfunctions and even the feared multiple organ dysfunction syndrome (MODS) $)^{4,5}$.

This worsening of the tissue lesions was called "oxygen paradox", described in 1978 by Hearse, Humprey, and Bulock ${ }^{6}$. Nowadays, it is known that the $\mathrm{I} / \mathrm{R}$ generates free radicals which act on the lipids, carbohydrates, proteins and nucleic acids, a phenomenon called "oxydative stress", and lead to changes in the cell function and structure, which might result in death ${ }^{7}$.

Another important agent involved in these aggressions, both locally and systemically is the inflammation triggered by $I / \mathrm{R}^{8-}$ ${ }^{10}$. Acute ischemia leads to the endothelium activation with increase in permeability and expression of several adhesion molecules. These molecules are crucial for the recruiting and infiltration of effector cells in the post-ischemic tissue. Nuclear factor Kappa $\mathrm{B}$ and macrophages are induced and activated, leading to the production of cytotoxic free radicals and inflammatory cytokines. During reperfusion, the adherent leukocites release oxygen reactive species and a variety of cytokines, thus increasing the inflammatory response $\mathrm{e}^{11,12}$.

The alpha tumor necrosis factor (TNF-alpha), also known as cachectin, is a strong pro-inflammatory cytokine, which has an important role in the immunological system during cell inflammation, proliferation and differentiation, and apoptosis ${ }^{13}$. This cytokine is produced by several cells, including hepatocytes,
$\mathrm{T}$ cells, neutrophils and magrophages ${ }^{14}$. It is one of the first cytokines to be produced during the inflammatory process and its release induces the synthesis of several other cytokines. Its production is stimulated by bacterial cytokines, complement, immunocomplement and surface proteins, which appear due to damage to the vascular endothelium integrity ${ }^{5}$.

Another consequence of the reperfusion injury is the increase in the intestinal permeability, leading to the translocation of bacterial endotoxins and consequent endotoxemia. Such endotoxin - a component of the external membrane of gramnegative bacteria cell wall, lumen intestinal colonizing agents can then go into extra-intestinal tissue and induce the production of free radicals and cytokines, which might enhance the development of MODS. It is important to point out the cyclic character of this process, since the initial damage to the intestinal barrier is probably caused by the excessive production of free radicals, primarily and inflammatory cytokines, complementary. This occurs because the free radicals produced during the reperfusion period are the main agents responsible for the injuries in organs which are distant from those that suffered ischemia ${ }^{5,15,16}$.

Considering that the ORS take part in the induction mechanism and the inflammation action, it is postulated that by reducing their formation, there will be reduction in the inflammation, minimizing the reperfusion injury. The ORS production occurs, mainly, in hypoxic cells, in which the ATP is metabolized in ADP, AMP, adenosine, inosine and finally in the xanthine oxidase substrates, hypoxanthine and xanthine. Then, the latter reacts with the xanthine oxidase during reperfusion, when the molecular oxygen is reintroduced in the tissue, to produce superoxide anion $\left(\mathrm{O}_{2}^{-}\right)$and hydrogen peroxide $\left(\mathrm{H}_{2} \mathrm{O}_{2}\right)^{17}$.

Because allopurinol and its main metabolite, the aloxanthine are competitive and non-competitive inhibitors, respectively, of the xanthine oxidase enzyme, it represents a therapeutic possibility to reduce the damage following $I / R$, through the ORS production reduction ${ }^{5}$.

Taking the above into consideration, the objective of this study was to investigate the potential protection effect of allpurinol in the reperfusion injury, through the determination of inflammatory response via serum TNF-alpha measurement in rats Wistar submitted to different ischemia times followed by reperfusion.

\section{Methods}

After being approved by the Universidade Estadual de Ponta Grossa (UEPG) Animal Use Ethical Committee (CEUA), process CEUA 019/2013. 
Sixty Wistar rats (Rattus norvegicus albinus), aged between 123 and 138 days, which weighed $256.3 \pm 8.48$ grams, supplied by the UEPG vivarium were used. The rats were kept at the vivarium throughout the experiment and only taken to the Operation and Surgery Technique laboratory when the procedure was carried out. The rats were randomly separated into two groups, control (C) and allopurinol (A), and each group was sub-divided into three groups, ischemia for two hours, ischemia for three hours and ischemia simulation, according to the description in Chart 1.

CHART 1 - Study groups organization.

\begin{tabular}{|c|c|c|c|}
\hline Groups & & Subgroups & $\mathrm{N}$ \\
\hline \multirow{3}{*}{$\begin{array}{l}\text { Control } \\
\text { (C) }\end{array}$} & $\mathrm{C}-2 \mathrm{~h}$ & $\begin{array}{c}\text { Treatment with physiological } \\
\text { solution, 2-hour ischemia and } \\
\text { 72-hour reperfusion. }\end{array}$ & 10 \\
\hline & C-3h & $\begin{array}{c}\text { Treatment with physiological } \\
\text { solution, 3-hour ischemia and } \\
\text { 72-hour reperfusion. }\end{array}$ & 10 \\
\hline & C-S & $\begin{array}{l}\text { Treatment with physiological } \\
\text { solution, ischemia simulation }\end{array}$ & 10 \\
\hline \multirow{3}{*}{$\begin{array}{l}\text { Alopurinol } \\
\text { (A) }\end{array}$} & $A-2 h$ & $\begin{array}{l}\text { Treatment with allopurinol, 2-hour } \\
\text { ischemia and 72-hour reperfusion. }\end{array}$ & 10 \\
\hline & A-3h & $\begin{array}{l}\text { Treatment with allopurinol, 3-hour } \\
\text { ischemia and } 72 \text {-hour reperfusion. }\end{array}$ & 10 \\
\hline & A-S & $\begin{array}{l}\text { Treatment with allopurinol, } \\
\text { ischemia simulation }\end{array}$ & 10 \\
\hline
\end{tabular}

Allopurinol rats received, through hard probe gavage, a $100 \mathrm{mg} / \mathrm{kg}$ dose of allopurinol an hour before the surgical procedure. While the rats in the control group received, through hard probe gavage, a dose of physiological solution equivalent to their weight, also an hour before the surgical procedure.

All rats were anesthetized with $50 \mathrm{mg} / \mathrm{kg}$ de Ketamin $\left(\right.$ Ketamin $\left.^{\circledR}\right)$ associated to $10 \mathrm{mg} / \mathrm{kg}$ de Xylazine $\left(\right.$ Calmiun $\left.^{\circledR}\right)$, which were injected via intramuscular into the calf muscles. After anesthetic induction, they had the abdominal hair shaved, were fixed in a supine position and submitted to antisepsis with iodine alcohol. Then, sterile drapes were put on the surgical field.

Then each rat was submitted to a laparotomy through midline xifopubic incision with opening of all abdominal wall planes and exposure of the abdominal cavity. The intestinal loops were removed from the peritoneal cavity and protected with sterilized gauze wetted in isotonic saline solution. The posterior parietal peritoneum was dissected and the vena cava was separated from the infrarenal aorta.

According to the subgroups plan (Chart 1), the aortic clamping was carried out for two hours (sub-groups $\mathrm{C}-2 \mathrm{~h}$ and A-2h) and three hours (sub-groups C-3h and A-3h), respectively. During these ischemia periods, the intestinal loops were replaced into the abdominal cavity and gauze wetted with isotonic saline solution was placed on the surgical wound to prevent liquid loss through evaporation. The anesthetic plan maintenance was carried out whenever necessary, with $25 \mathrm{mg} / \mathrm{kg}$ Ketamin $\left(\operatorname{Ketamin}^{\circledR}\right)$, associated to $5 \mathrm{mg} / \mathrm{kg}$ Xylazine $\left(\right.$ Calmiun $\left.^{\circledR}\right)$, injected via intramuscular into the calf muscles.

When the ischemia periods finished, the clamps were removed and the surgical wound was closed with running sutures, in two planes, with Vicryl ${ }^{\circledR} 000$ (Johnson \& Johnson).

The subgroups C-S and A-S did not undergo ischemia, and the only procedure was the infrarenal aorta vena cava dissection, kept for three hours and the closure of the surgical wound, as previously described.

All rats were sent to the vivarium and kept for 72 hours being fed with specific food for the species (Nuvilab - Nuvital ${ }^{\circledR}$ ) and water ad libitum.

Seventy-two hours after the surgical procedure, all rats were anesthetized with $50 \mathrm{mg} / \mathrm{kg}$ Ketamina $\left(\operatorname{Ketamin}^{\circledR}\right)$, associated to $10 \mathrm{mg} / \mathrm{kg}$ Xylazine $\left(\right.$ Calmiun $\left.{ }^{\circledR}\right)$. The antisepsis of the thoracic region skin was carried out with iodine alcohol and blood was collected through cardiac puncture. Consequently, the exsanguinations led the rats to a cardiopulmonary arrest. The blood was then centrifuged and each rat plasma was transferred to three glass containers ( $1 \mathrm{ml}$ each), for the measurement of TNF-alpha in each of the samples, through the ELISA method. The reactive set BIOTRA Tumor NecrosisFactor ELISA System (Amersham Pharmacia code RPN 2718 ${ }^{\circledR}$ ) was employed.

This dosage was based on the quantitative immunoenzymatic technique, in which a specific monoclonal antibody anti-TVF-alpha is fixed on a Terazaki plate for later capture of the TNF-alpha antigen. The plasma samples were distributed in each of the plate holes, in $50 \mu \mathrm{l}$ volumes; then they were incubated and developed with peroxidase-conjugated anti-TNF-alpha monoclonal antibodies, which by reacting with the hydrogen peroxide, develop a color which is measurable in spectrophotometer at $450 \mathrm{~nm}$ wavelength. The color development indicates the presence of TNF-alpha in the sample, which is directly proportional to the spectrophometric reading. 
The groups results were expressed as average and standard deviation, obtained between the TNF-alpha dosages triplicates. The ANOVA variance analysis was employed to the data obtained within the same subgroup, and the Tukey test was employed to the paired comparisons between subgroups, in order to verify which subgroups differed from each other. Finally, $\mathrm{p}<0.05$ was considered statistically significant.

\section{Results}

The TNF-alpha dose results were obtained in triplicate in order to evaluate this data. In the statistical evaluation of findings, there was no significant difference between the samples average within the subgroups ( $\mathrm{p}>0.05)$, as shown in Tables 1 and 2 .

TABLE 1 - Validation of TNF-alpha (pg/ml) dosages results obtained in triplicate in samples of the control group.

\begin{tabular}{|c|c|c|c|c|c|c|c|c|c|}
\hline \multirow{2}{*}{ Rats } & \multicolumn{3}{|c|}{$\mathrm{C}-2 \mathrm{~h}$} & \multicolumn{3}{|c|}{$\mathrm{C}-3 \mathrm{~h}$} & \multicolumn{3}{|c|}{ C-S } \\
\hline & A & $\mathrm{B}$ & $\mathrm{C}$ & A & B & $\mathrm{C}$ & A & B & $\mathrm{C}$ \\
\hline 1 & 153 & 163 & 174 & 650 & 648 & 636 & 33 & 32 & 34 \\
\hline 2 & 216 & 226 & 219 & 716 & 723 & 715 & 36 & 37 & 35 \\
\hline 3 & 387 & 374 & 381 & 733 & 748 & 698 & 48 & 45 & 43 \\
\hline 4 & 475 & 482 & 482 & 830 & 841 & 795 & 25 & 28 & 31 \\
\hline 5 & 376 & 378 & 366 & 623 & 633 & 626 & 43 & 41 & 42 \\
\hline 6 & 418 & 422 & 414 & 725 & 719 & 715 & 38 & 36 & 33 \\
\hline 7 & 416 & 418 & 422 & 901 & 816 & 809 & 32 & 29 & 32 \\
\hline 8 & 435 & 422 & 419 & 775 & 762 & 754 & 41 & 39 & 42 \\
\hline 9 & 221 & 232 & 229 & 682 & 683 & 656 & 43 & 44 & 46 \\
\hline 10 & 374 & 361 & 359 & 986 & 979 & 912 & 34 & 33 & 34 \\
\hline $\mathrm{p}$ & \multicolumn{3}{|c|}{0.9154} & \multicolumn{3}{|c|}{0.7851} & \multicolumn{3}{|c|}{0.9357} \\
\hline Average & 347.4 & 348.1 & 346.7 & 692.9 & 686.7 & 665.4 & 34.0 & 33.3 & 34.1 \\
\hline Standard-deviation & 109.5 & 104.4 & 103.0 & 253.7 & 247.2 & 235.2 & 12.7 & 11.8 & 11.5 \\
\hline
\end{tabular}

TABLE 2 - Validation of TNF-alpha (pg/ml) dosages results obtained in triplicate in samples of the allopurinol group.

\begin{tabular}{|c|c|c|c|c|c|c|c|c|c|}
\hline \multirow{2}{*}{ Rats } & \multicolumn{3}{|c|}{ A-2h } & \multicolumn{3}{|c|}{ A-3h } & \multicolumn{3}{|c|}{ A-S } \\
\hline & A & B & $\mathrm{C}$ & A & $\mathrm{B}$ & $\mathrm{C}$ & A & $\mathrm{B}$ & $\mathrm{C}$ \\
\hline 1 & 36 & 36 & 37 & 175 & 178 & 184 & 28 & 23 & 27 \\
\hline 2 & 47 & 49 & 52 & 213 & 226 & 237 & 36 & 39 & 36 \\
\hline 3 & 28 & 29 & 33 & 247 & 264 & 276 & 23 & 28 & 29 \\
\hline 4 & 12 & 15 & 15 & 362 & 351 & 358 & 31 & 34 & 32 \\
\hline 5 & 43 & 44 & 44 & 153 & 163 & 174 & 20 & 22 & 26 \\
\hline 6 & 38 & 39 & 37 & 361 & 370 & 296 & 38 & 37 & 35 \\
\hline 7 & 35 & 36 & 34 & 478 & 489 & 445 & 32 & 33 & 34 \\
\hline 8 & 27 & 28 & 31 & 334 & 344 & 347 & 44 & 43 & 44 \\
\hline 9 & 28 & 29 & 32 & 207 & 214 & 286 & 41 & 39 & 41 \\
\hline 10 & 35 & 37 & 36 & 226 & 231 & 231 & 39 & 38 & 37 \\
\hline $\mathrm{p}$ & \multicolumn{3}{|c|}{0.8762} & \multicolumn{3}{|c|}{0.9797} & \multicolumn{3}{|c|}{0.9592} \\
\hline Average & 32.9 & 34.2 & 35.1 & 275.6 & 283 & 283.4 & 33.2 & 33.6 & 34.1 \\
\hline Standard-deviation & 9.8 & 9.5 & 9.5 & 103.4 & 102.7 & 83.5 & 7.8 & 7.1 & 5.8 \\
\hline
\end{tabular}


The average and the standard deviation of the TNF-alpha dosages from each subgroup are presented in Table 3.

TABLE 3 - TNF-alpha (pg/ml) dosages average and standard deviation in subgroups.

\begin{tabular}{ccccccc}
\hline Groups and & \multicolumn{3}{c}{ Control } & \multicolumn{3}{c}{ Allopurinol } \\
Subgroups & C-2h & C-3h & C-S & A-2h & A-3h & A-S \\
\cline { 2 - 7 } Average & 347.1 & 749.6 & 37.0 & 34.1 & 280.7 & 33.6 \\
$\begin{array}{c}\text { Standard- } \\
\text { deviation }\end{array}$ & 101.9 & 99.6 & 5.8 & 9.3 & 93.6 & 6.7 \\
\hline
\end{tabular}

The comparison between the results from each subgroup is exhibited in Table 4.

TABLE 4 - Comparison between average and standarddeviations of TNF-alpha dosages in the subgroups.

\begin{tabular}{|c|c|c|c|c|c|}
\hline Comparisons & Group & & Group & $\mathrm{p}$ & Conclusion \\
\hline $\begin{array}{c}\text { Between } \\
\text { simulation in } \\
\text { each group }\end{array}$ & $\mathrm{C}-\mathrm{S}$ & $\mathrm{X}$ & A-S & $>0,05$ & NS \\
\hline \multirow{4}{*}{$\begin{array}{l}\text { Between } \\
\text { simulation in } \\
\text { each group and } \\
\text { the ischemia } \\
\text { subgroups }\end{array}$} & \multirow{2}{*}{ C-S } & $\mathrm{X}$ & $\mathrm{C}-2 \mathrm{~h}$ & $<0,001$ & $\mathrm{~S}$ \\
\hline & & $X$ & C-3h & $<0,001$ & S \\
\hline & \multirow{2}{*}{ A-S } & $\mathrm{X}$ & $A-2 h$ & $>0,05$ & NS \\
\hline & & $X$ & A-3h & $<0,001$ & $\mathrm{~S}$ \\
\hline \multirow{4}{*}{$\begin{array}{l}\text { Between } \\
\text { ischemia } \\
\text { subgroups }\end{array}$} & $\mathrm{C}-2 \mathrm{~h}$ & $X$ & $\mathrm{C}-3 \mathrm{~h}$ & $<0,001$ & S \\
\hline & $A-2 h$ & $X$ & A-3h & $<0,001$ & S \\
\hline & $\mathrm{C}-2 \mathrm{~h}$ & $X$ & $A-2 h$ & $<0,001$ & S \\
\hline & C-3h & $\mathrm{X}$ & A-3h & $<0,001$ & S \\
\hline
\end{tabular}

NS: non-significant; S- significant.

\section{Discussion}

The I/R and consequent oxidative stress are associated to countless clinical and surgical conditions such as: sepsis, arterial occlusion trauma, cardiac arrest, thrombosis, embolism, vasospasm, transplant and organ resections, encephalic vascular accident and myocardial infarction ${ }^{18}$. Therefore, a lot of research has been developed aiming at reducing the inflammation that follows $\mathrm{I} / \mathrm{R}$ and thus reduce the damage to several organs such as heart, brain, lungs and intestines ${ }^{8-11,16}$.

Stahlke ${ }^{19}$ proposed an experimental model to study the ischemia and reperfusion injury. His model consisted of rats that underwent the clamping of the infrarenal aorta through a laparotomic access. The same experimental model was used in our study because it was found to be reproducible and easily understandable.

The inflammation reduction procedures require that the means to measure post I/R inflammatory activity be established. Li et al. ${ }^{11}$ used the TNF-alpha, the interleukin (IL)-1 beta, the IL-6 and the inducible nitric oxide synthase in this measurement after hepatic I/R. Kurtoglu et al. ${ }^{20}$ also employed the TNF-alpha, IL-1beta and IL-6 measurement post spinal cord I/R. Wang et al. ${ }^{8}$ measured the TNF-alpha expression and the Kappa B Nuclear Factor post brain I/R. Gormus et al. ${ }^{21}$ tested TNF-alpha levels, IL-6, IL-8 and IL-10 (the latter being a powerful anti-inflammatory cytokine) in patients that had been submitted to myocardial revascularization surgery with extracorporeal circulation. Sladojevic et al. ${ }^{22}$ in his study on brain I/R measured over 62 cytokines, including TNF-alpha, IL-1 alpha, IL-12, interferon gamma and chemokines. In this study, the TNF-alpha dose adopted to measure the inflammatory cascade activation promoted by the oxidative stress induced by ischemia and reperfusion.

Other methods described in the literature to evaluate the consequences of $\mathrm{I} / \mathrm{R}$ include the tissue anatomopathologic study such as the intestine ${ }^{14,16}$ and the skeletal muscle, the quantification of plasmatic endotoxin ${ }^{15,16}$, superoxide dismutase ${ }^{15,16,23}$ (SOD, an enzyme which removes the superoxide radical by accelerating its conversion into hydrogen peroxide), xanthine oxidase ${ }^{23}$, diamine oxidase $^{15,16}$ ( DAO, an enzyme primarily synthesized by the gastrointestinal mucosa cells, which reflect this tissue maturity and integrity), myeloperoxidase $\mathrm{e}^{13,14,16}(\mathrm{MPO}$, an indicator of neutrophil activity), malondialdehyde ${ }^{7,16,23}$ (MDA, an indicator of lipid peroxidation), total antioxidant capacity ${ }^{7}$, and nitric acid ${ }^{7}$ (NO, a vasodilator which indicates endothelial response).

Allopurinol has been studied, both in animal experimentation models $\mathrm{s}^{5,14,23}$ as well as in humans ${ }^{10,21}$, aiming at determining its potential protective effect in reperfusion injury. Gormus et al. ${ }^{21}$, and Ilhan et al. ${ }^{14}$ obtained statistically significant decrease in TNF-alpha in individuals treated with allopurinol, when compared to the individuals in the control group in $I / R$ events. Rachmat et al. ${ }^{10}$, despite having observed clear reduction in TNF-alpha in patients of the allopurinol group, did not obtain statistical significance in their findings, probably due to insufficient number of samples.

The experimental model in this study showed that allopurinol was able to decrease TNF-alpha significantly, when compared to the equivalent control subgroups (C-2h X A-2h and C-3h X A-3h). Also, the fact that the comparison A-S X A-2h has presented $p>0.05$ indicates that the allopurinol almost completely 
retains the TNF-alpha induction in ischemia up to two hours, and partially when the time is three hours (A-S X A-3h, $<<0.05)$. This result suggests that allopurinol has an ischemia time slot in which its efficacy is maximized, and also that, probably, after certain time it would not act effectively any more.

It was also demonstrated that this pro-inflammatory cytokine induction increases with the ischemia time (C-2h X C-3h and $\mathrm{A}-2 \mathrm{~h} X \mathrm{~A}-3 \mathrm{~h})$. It is known that the ischemia and hypoxia process reversibility is directly related to the ischemia time, besides depending on each tissue cell metabolic necessities, collateral circulation supply and local humoral factors ${ }^{5}$. The findings in this study highlighted the fact that the post $\mathrm{I} / \mathrm{R}$ inflammation is also related to the ischemia time, in agreement with Rocha et $a l .{ }^{3}$ findings. The fact that the difference between C-S x A-S was not statistically significant ( $\mathrm{p}>0.05$ ) only demonstrated that the allpurinol treatment did not alter the serum TNF-alpha levels in the absence of ischemia.

Several other methods, whose aim is to prevent reperfusion injury, have been investigated recently, mainly because, due to the several physiopathological mechanisms involved in the reperfusion injury, it is difficult to achieve effective protection when focusing on single mediators or mechanisms ${ }^{24}$. Among these are the intra-cellular-1 adhesion anti-molecule monoclonal antibodies (ICAM-1, an important mediator in the firm adhesion of netrophils to the vascular endothelium), methylene blue (which can act as an electron alternative acceptor for the xanthyne oxidase, competing with the molecular oxygen for their transfer) ${ }^{14}$, deferrioxamine (used as antioxidant) ${ }^{25}$, pentoxifylline (antioxidant, which inhibits directly the superoxide anion and blocks indirectly the xanthyne oxidase action) ${ }^{3}$, vimpocetina (cerebral vasodilator $)^{8}$, penehyclidinehydrochloride (a new anticholinergic drug, with potential antioxidant and cytoprotective activity) $)^{15}$, ascorbic acid and alpha-tocopherol (anti-oxidants) ${ }^{23}$, IL-10 ${ }^{26}$, anti-TNF-alpha antibodies $^{26}$, among several others.

Also, other techniques which have been researched are the ischemic preconditioning (IPC) and the ischemic postconditioning $(\mathrm{PoC})$. The IPC consists of short periods of arterial occlusion, followed by short repeated reperfusion periods before initiating the ischemia. However, considering that in most of the situations the ischemia is identified after installed, there are few opportunities for the use of IPC. Therefore, the PoC technique was developed, which consists of inducing one or more short reperfusion cycles followed by ischemia, immediately after the ischemia phase, but before the permanent reperfusion occurs ${ }^{27}$.
In this study experimental model, the allopurinol was injected one hour before the ischemia, therefore, its clinical applicability was restricted to elective ischemia conditions. For greater coverage, different moments of allopurinol application must be researched.

\section{Conclusion}

The allopurinol reduced serum TNF-alpha concentrations when used at different ischemia times followed by reperfusion, which might indicate reduction of the inflammation provoked by reperfusion injury.

\section{References}

1. Procianoy RS, Silveira RC. Síndrome hipóxico-isquêmica. J Pediatr. 2001;77(Supl.1). PMID: 14676894.

2. Rocha BC, Mendes RRS, Lima GV, Albuquerque GS, Araújo LL, Jesus MNSD, Washington LCS, Carreiro MC. Modelo experimental de isquemia: reperfusão intestinal por clampeamento de aorta abdominal em ratos Wistar. Rev Col Bras Cir. 2012 June;39(3):20710. doi: 10.1590/S0100-69912012000300008.

3. Brasileiro JL, Fagundes DJ, Miiji LON, Oshima CTF, Teruya R, Marks G, Inouye CM, Santos MA. Isquemia e reperfusão de músculo sóleo de ratos sob ação da pentoxifilina. J Vasc Bras. 2007 Mar;6(1):50-63. doi: 10.1590/S1677-54492007000100008.

4. Castro e Silva Jr OD, Centurion S, Pacheco EG, Brisotti JL, Oliveira $\mathrm{AF}$, Sasso KD. Aspectos básicos da lesão de isquemia e reperfusão e do pré-condicionamento isquêmico. Acta Cir Bras. 2002;17(Suppl 3):96-100. doi: 10.1590/S0102-86502002000900020.

5. Gomes RZ. Efeito do alopurinol sobre as repercussões da isquemia e reperfusão de membros caudais de ratos Wistar (Tese). Curitiba: Universidade Federal do Paraná; 2007.

6. Hearse DJ, Humprey WG, Bulock GR. The oxygen paradox and the calcium paradox: two facets of the same problem? J Moll Cell Cardiol. 1978;10:641-68. PMID: 691070.

7. Francisco Neto A, Silva JCCB, Fagundes DJ, Percário S, Novo NF, Juliano Y, Moreira Neto AA. Estudo das alterações oxidativas, da capacidade antioxidante total e do óxido nítrico, em ratos submetidos à isquemia e reperfusão de membros posteriores. Acta Cir Bras. 2005 Apr;20(2):134-9. doi: 10.1590/S0102-86502005000200006.

8. Wang H, Zhang K, Zhao L, Tang J, Gao L, Wei Z. Anti-inflammatory effects of vinpocetine on the functional expression of nuclear factorkappa B and tumor necrosis factor-alpha in a rat model of cerebral ischemia-reperfusion injury. Neurosci Lett. 2014 Apr;556: 247-51. PMID: 24598438.

9. Chen S, Yin ZJ, Jiang C, Ma ZQ, Fu Q, Qu R, Ma SP. Asiaticoside attenuates memory impairment induced by transient cerebral ischemia-reperfusion in mice through anti-inflammatory mechanism. Pharmacol Biochem Behav. 2014 Mar 12;122:7-15. PMID: 24631487.

10. Rachmat FD, Rachmat J, Sastroasmoro S, Wanandi SI. Effect of allopurinol on oxidative stress and hypoxic adaptation response during surgical correction of tetralogy of fallot. Acta Med Indones. 2013 Apr;45(2):94-100. PMID: 23770788.

11. Li CX, Ng KT, Shao Y, Liu XB, Ling CC, Ma YY, Geng W, Qi X, Cheng Q, Chung SK, Lo CM, Man K. The inhibition of aldose reductase attenuates hepatic ischemia-reperfusion injury through 
reducing inflammatory response. Ann Surg. 2014;260(2):317-28. PMID: 24699020.

12. Boros P, Bromberg JS. New cellular and molecular immune pathways in ischemia/reperfusion injury. Am J Transplant. 2006;6(4):652-8. PMID: 16539620.

13. Zelová $H$, Hošek J. TNF- $\alpha$ signalling and inflammation: interactions between old acquaintances. Inflamm Res. 2013 Jul;62(7):641-51. PMID: 23685857.

14. Ilhan $\mathrm{H}$, Alatas $\mathrm{O}$, Tokar B, Çolak O, Paşaoĝlu O, Koku N. Effects of the anti-ICAM-1 monoclonal antibody, allopurinol, and methylene blue on intestinal reperfusion injury. J Pediatr Surg. 2003 Nov;38(11):1591-5. PMID: 14614706.

15. Zhang Y, Leng YF, Xue X, Zhang Y, Wang T, Kang YQ. Effects of penehyclidine hydrochloride in small intestinal damage caused by limb ischemia-reperfusion. World J Gastroenterol. 2011 Jan;17(2):254-9. PMID: 21246001.

16. Leng YF, Zhang Y, Zhang Y, Xue X, Wang T, Kang YQ. Ischemic post-conditioning attenuates the intestinal injury induced by limb ischemia/reperfusion in rats. Braz J Med Biol Res. 2011 May;44(5):411-7. PMID: 21468513.

17. Zweier JL, Talukder MA. The role of oxidants and free radicals in reperfusion injury. Cardiovasc Res. 2006 May;70(2):181-90. PMID: 16580655

18. Somaio Neto F, Ikejiri AT, Bertoletto PR, Chaves JC, Teruya R, Fagundes DJ, Taha MO. Expressão gênica associada ao estresse oxidativo no coração de camundongo após isquemia intestinal. Arq Bras Cardiol. 2014 Feb;102(2):165-73. PMID: 24346830.

19. Stahlke PH. Modelo experimental de endotoxemia em ratos submetidos à isquemia e reperfusão de membros caudais (Dissertação). Curitiba: Universidade Federal do Paraná, Setor de Ciências da Saúde; 2001.

20. Kurtoglu T, Basoglu H, Ozkisacik EA, Cetin NK, Tataroglu C, Yenisey C, Discigil B. Effects of cilostazol on oxidative stress, systemic cytokine release, and spinal cord injury in a rat model of transient aortic occlusion. Ann Vasc Surg. 2014 Feb;28(2):479-88. PMID: 24485778.

21. Gormus ZI, Celik JB, Ergene N, Gormus N, Baltaci AK. Does preoperative administration of allopurinol protect the lungs from ischemia-reperfusion injury occuring during cardiopulmonary bypass? Bratisl Lek Listy. 2013;114(10):561-5. PMID: 24156678.

22. Sladojevic N, Stamatovic SM, Keep RF, Grailer JJ, Sarma JV, Ward PA, Andjelkovic AV. Inhibition of junctional adhesion molecule-A/ LFA interaction attenuates leukocyte trafficking and inflammation in brain ischemia/reperfusion injury. Neurobiol Dis. 2014;67:57-70. PMID: 24657919.

23. Erkut B, Özyazıcıoğlu A, Karapolat BS, Koçoğulları CU, Keles S, Ateş A, Gundogdu C, Kocak H. Effects of ascorbic Acid, alphatocopherol and allopurinol on ischemia-reperfusion injury in rabbit skeletal muscle: an experimental study. Drug Target Insights. 2007 Nov;2:249-58. PMID: 21901079.

24. Papadopoulos D, Siempis T, Theodorakou E, Tsoulfas G. Hepatic ischemia and reperfusion injury and trauma: current concepts. Arch Trauma Res. 2013 Aug;2(2):63-70. PMID: 24396796.

25. Nastos C, Kalimeris K, Papoutsidakis N, Defterevos G, Pafiti A, Kalogeropoulou H, Zerva L, Nomikos T, Kostopanagiotou G, Smyrniotis V, Arkadopoulos N. Antioxidant treatment attenuates intestinal mucosal damage and gut barrier dysfunction after major hepatectomy. Study in a porcine model. J Gastrointest Surg. 2011 May;15(5):809-17. PMID: 21380631.

26. Souza DG, Teixeira MM. The balance between the production of tumor necrosis factor-alpha and interleukin-10 determines tissue injury and lethality during intestinal ischemia and reperfusion. Mem Inst Oswaldo Cruz. 2005 Mar;100(Suppl 1):59-66. PMID: 15962100
27. Dos Santos CH, Pontes JC, Gomes OM, Miiji LN, Bispo MA. Avaliação do pós-condicionamento isquêmico no tratamento da isquemia mesentérica. Estudo experimental em ratos. Rev Bras Cir Cardiovasc. 2009;24(2):150-6. PMID: 19768293.

\section{Correspondence:}

Ricardo Zanetti Gomes

Universidade Estadual de Ponta Grossa, Departamento de Medicina Avenida General Carlos Cavalcanti, 4748

84030-900 Ponta Grossa - PR Brasil

Tel.: (55 42)3220-3000 / 9972-0704

zanetticons@uol.com.br

Received: Oct 16, 2015

Review: Dec 17, 2015

Accepted: Jan 19, 2016

Conflict of interest: none

Financial source: none

${ }^{1}$ Research performed at Experimental Surgery and Operation Technique Laboratory, Medicine Department, Universidade Estadual de Ponta Grossa (UEPG), Ponta Grossa-PR, Brazil. 